\title{
PERAN MOTOR EDUCABILITY DI DALAM MENINGKATAN KETERAMPILAN OLAHRAGA PADA PEMBELAJARAN PENJAS
}

\author{
Oleh: \\ Heru Syarli Lesmana \\ (Dosen Universitas Negeri Padang)
}

\begin{abstract}
Abstrak
Seluruh potensi dan keterampilan olahraga yang ada pada peserta didik seharusnya dapat dikembangkan dan dibina melalui proses pembelajaran penjasyang ada disekolah agar nantinya mereka dapat menggunakan potensi yang miliki sebaik mungkin baik di secara pribadi dan berguna untuk masyarakat serta lingkungan. Seorang yang bergelut didalam dunia olahraga khususnya bidang pendidikan olahraga memahami setiap aspek yang mempengaruhi perkembangannya sehingga nanti dapat berguna dalam proses pembelajaran itu sendiri. Mengetahui kemampuan belajar gerak (motor educability) peserta didik sangatlah penting agar seorang pendidik dapat mengetahui kelebihan dan kekurangan seorang peserta didiknya, sehingga nantinya dapat menyesuaikan dengan gaya mengajar melatih ataupun mengajar, program serta perencanaan, fasilitas yang dibutuhkan. Sebaliknya olahraga juga dapat membantu perkembangan kognitif peserta didik dengan berbagai latihan didalam pendidikan jasmani.
\end{abstract}

Kata Kunci: Keterampilan Olahraga, Pembelajaran Penjas, Motor Educability

\section{THE ROLE OF MOTOR EDUCABILITY IN ENHANCING SPORTS SKILL AT PHYSICAL EDUCATION LEARNING}

\begin{abstract}
All potential and existing sports skills in learners should be developed and nurtured through the existing learning process in school so that later they can use the potential that is as good as possible both in person and useful for society and the environment. A person who lives in the world of sports, especially the field of sports education to understand every aspect that affects the development so that later can be useful in the learning process it self. Knowing the ability to learn the motion (motor educability) of learners is important so that an educator can know the advantages and disadvantages of a learner, so that later can adjust to the style of teaching or teaching, program and planning, facilities needed. Instead exercise can also help the cognitive development of learners with various exercises in physical education.
\end{abstract}

Keyw ords: Sports Skills, Physical Education, Motor Educability 


\section{A. Pendahuluan}

Pada masa kini pembinaan dan pengembangan ilmu olahraga telah menjadi prioritas dalam ranah ke ilmua, hal ini dikarenkan salah satu indikator dan faktor manusia yang berkualitas adalah manusia yang dapat memiliki tingkat kesehatan dan kebugaran jasmani yang tinggi, baik secara fisik maupun psikologis. Didalam upaya peningkatkan kualitas sumber daya manusia, ilmu olahraga diarahkan pada peningkatan kualitas jasmani, mental dan rohani, serta ditunjukan untuk membentuk watak dan kepribadiaan, disiplin dan sportivitas yang tinggi, serta peningkatan prestasi, meningkatkan moral bangsa. Hal ini sesuai undang-undang nomor 3 tahun 2005 tentang Sistem Keolahragaan Nasional. Tujuan pemerintah dalam bidang olahraga terdapat dalam BAB 2 Pasal 4 yang berbunyi:

"Keolahragaan nasional bertujuan memelihara dan meningkatkan kesehatan dan kebugaran, prestasi, kualitas manusia, menanamkan nilai moral dan akhlak mulia, sportifitas, disiplin, mempererat dan membina persatuan dan kesatuan bangsa, memperkokoh ketahanan nasional, serta meningkatkan harkat, martabat dan kehormatan bangsa."

Tercapainya tujuan keolahragaan nasional akan terlihat dari tumbuh dan berkembangnya generasi yang sehat jasmani dan rohani, bugar, berkualitas, bermoral dan berakhlak mulia, sportif, disiplin, yang nantinya akan berdampak positif terhadap pembangunan perkembangan secara nasional dibidang-bidang lainnya.

Pada dasarnya pendidikan jasmani merupakan bagian integral dari sistem pendidikan secara keseluruhan. Maka dari itu, pelaksanaan pendidikan jasmani diarahkan pada pencapaian tujuan sistem tersebut. Tujuan pendidikan jasmani tidak hanya mengembangkan ranah fisik, tetapi juga mengembangkan aspek biologis, kesehatan, kebugaran, keterampilan berfikir, stabilitas emosional, keterampilan sosial, penalaran dan tindakan moral melalui aktivitas olahraga. Oleh karena itu, pendidikan jasmani juga memberikan pembekalan pengalaman belajar yang diarahkan untuk membina, sekaligus membentuk gaya hidup sehat dan aktif sepanjang hayat. 
Pendidikan jasmani adalah suatu media dalam mendorong perkembangan motorik, kemampuan fisik pengetahuan dan penalaran, penghayatan nilai-nilai (sikap, mental, emosional, spiritual, dan sosial), serta pembiasan pola hidup sehat yang bertujuan untuk merangsang pertumbuhan dan perkembangan secara seimbang.

Pendidikan jasmani memiliki peran yang sangat penting dalam penyelenggaraan pendidikan sebagai suatu proses pembinaan manusia yang berlansung seumur hidup. Hal ini dikarenakan memberikan kesempatan pada siswa untuk terlibat langsung dalam berbagai pengalaman belajar melalui aktivitasnya. Didalam pendidikan jasmani, aktivitas yang diberikan dalam pembelajaran harus mendapatkan sentuhan metodik yang tepat. Oleh karena itu, nantinya aktivitas yang dilakukan dapat mencapai tujuan pengajaran.

Dalam proses pembelajaran pendidikan jasmani guru harus dapat memahami dan mengajarkan berbagai keterampilan gerak dasar, dan strategi permainan/olahraga, serta internalisasi nilai-nilai (sportivitas, jujur kerjasama, dan lain-lain) dari pembiasan pola hidup sehat. Oleh karena itu, pelaksanaannya bukan hanya melalui pengajaran konvensional di dalam kelas yang bersifat teoritis, namun lebih banyak melibatkan pengalaman mengenai unsur fisik mental, intelektual, emosional, dan sosial. Selain dari itu, melalui pendidikan jasmani siswa dapat memperoleh berbagai pengalaman untuk mengungkapkan kesan pribadi yang menyenangkan, kreatif, inovatif, terampil, serta potensial.

Seorang guru harus mampu mengembangkan pembelajaran yang efektif, disamping harus memahami dan memperhatikan karakteristik dan kebutuhan siswa. Baik kegiatan intrakurikuler dan ekstrakurikuler merupakan wadah yang sangat baik dalam pengembangan kemampuan olahraga, kegiatan ini juga dapat membantu siswa dalam dalam menuntaskan kompetensi mereka dalam mata pelajaran olahraga. Oleh karena itu kegiatan ini harus didampingi oleh pembina yang berada dalam dunia olahraga itu sendiri, seorang guru harus mendampingi siswanya dalam berlatih suatu cabang olahraga. Didalam kegiatan pendidikan 
jasmani terdapat banyak hal yang harus diperhatikan dalam pemilihan kecabangan masing-masing yaitu, kondisi fisik, postur tubuh, motivasi, minat, bakat, dan juga kecerdasan dalam berolahraga.

Seseorang yang memiliki kemampuan intelligensi (IQ) tinggi, memiliki kemampuan berfikir cepat dan mampu mengambil keputusan cepat dan tepat. Pada umunya permainan olahraga sangat membutuhkan kemampuan IQ yang tinggi karena ketika bermain sering kali dihadapkan dengan situasi-situasi yang memerlukan pengambilan keputusan cepat dan tepat (Syafruddin, 2013: 26). Keterampilan berolahraga dapat dimaksimalkan dengan proses pendidikan yang benar, oleh karena itu para pendidik harus mempunyai pemahaman bahwa olahraga juga dipandang sebagai salah satu tingkat kecerdasan yang sebenarnya wajib dilatih oleh manusia, yaitu kecerdasan kinestetik. Kecerdasan kinestetik merupakan kemampuan manusia didalam melakukan aktifitas yang melibatkan anggota tubuh dengan benar, baik yang didapat secara pribadi maupun yang dipelajari. Dengan kata lain kecerdasan kinestetik bisa dikatakan bakat yang mempengaruhi kesuksesan berolahraga. Salah satu poin penting dalam meningkatkan kecerdasan ini adalah dengan memahami kemampuan memahami gerakan (motor educability). Dengan pengetahuan mengenai motor educability seorang siswa, diharapkan nantinya seorang pendidik dapat memaksimal kemampuan berolahraga mereka.

Memahami kecerdasan kinestetik (motor educability) sebagai bagian dari proses pembelajaran sangatlah penting, hal ini dikarenakan kegiatan pembelajaran merupakan wadah yang sangat tepat untuk siswa yang ingin mengembangkan potensi, khususnya dalam bidang olahraga. Oleh itu perlu dipahami bagaimana peran motor educability dalam meningkatkan keterampilan berolahraga sehingga kegiatan pembelajaran penjas dapat terlaksana dengan efektif. 


\section{B. PEMBAHASAN}

\section{Pendidikan Jasmani}

Lingkungan belajar diatur secara seksama untuk meningkatkan pertumbuhan dan perkembangan seluruh ranah, jasmani, psikomotor, kognitif, dan afektif setiap siswa. Dari penjelasan teori diatas dapat di artikan bahwa pendidikan jasmani merupakan suatu cara yang dilakukan manusia dalam memperoleh pengetahuan olahraga dan mengembangkannya sesuai dengan pengalaman sehingga berdampak pada perubahan pola pikir, prilaku, dan karakter seseorang dalam melakukan aktivitas jasmani kearah yang lebih baik. Hal ini sesuai dengan yang dijelaskan Samsudin (2013: 146) yaitu, pendidikan jasmani adalah suatu proses pembelajaran melalui aktivitas jasmani yang didesain untuk meningkatkan kebugaran jasmani, mengembangkan keterampilan motorik, pengetahuan dan perilaku hidup sehat dan aktif, sikap sportif dan kecerdasan emosi.

Pengembangan keterampilan olahraga melalui pendidikan jasmani terdapat dua proses kegiatan yang akan dilakukan untuk tercapainya tujuan pendidikan tersebut yaitu kegiatan intrakurikuler dan kegiatan ekstrakurikuler. Kegiatan intrakurikuler menurut KBBI online (2016) adalah kegiatan siswa disekolah atau mahasiswa di kampus yang sesuai dan sejalan dengan komponen kurikulum. Sedangkan kegiatan ekstrakurikuler adalah kegiatan peserta didik diluar jam belajar kurikulum standard dan wajib. Walaupun dilaksanakan diluar jam belajar wajib akan tetapi kegiatan ekstrakurikuler berperan penting dalam suksesnya proses pengajaran intrakurikuler.

\section{Motor Educability}

Menurut uraian Pino dan Wittermans (dalam Gatot Jariono, 2011), motor educability berasal dari bahasa Inggris, yaitu motor artinya bergerak, educatic artinya pengetahuan, dan ability artinya kemampuan. Dari rangkaian kata diatas terbentuk istilah motor educability yang memberikan pengertian kemampuan umum bagi seseorang dalam menguasai atau menerima gerakan 
baru. Cratty dalam Lutan (1988: 115) mengatakan istilah motor educability adalah sudah menjadi suatu kata yang cukup popular di kalangan aktivis olahraga, hal ini dikarenakan membahas tentang cepat lambatnya seseorang menguasai suatu keterampilan baru secara cermat. Dari penjelasan diatas dapat diketahui bahwa kemampuan motor educability seseorang dapat menunjang proses dalam mempelajari sebuah keterampilan gerak.

Scanidt dalam Lutan (1988: 76) menyatakan bahwa "Kemampuan diartikan sebagai ciri individu yang diwariskan dan relatif abadi yang mendasari serta medukung terbentuknya keterampilan". Namun kita tetap tidak boleh mengabaikan latihan, karena latihan merupakan faktor pendukung dalam meningkatkan secara totalitas baik aspek fisik maupun psikis. Dalam memperoleh kemampuan motor educability tidaklah harus melalui proses latihan layaknya kondisi fisik. Tetapi, kemampuan tersebut dapat diperoleh dari pertumbuhan yang baik serta usia yang nantinya akan mempengaruhi kemampuan bergerak, berpikir, dan belajar termasuk kecakapan dasar atau intelegensi yang dimiliki oleh setiap individu.

Cratty dalam Lutan (2005:116) menjelaskan bahwa "motor educability diartikan sebagai kemampuan umum untuk mempelajari tugas secara cepat dan cermat". Tapi, sekalipun motor educability merupakan kemampuan dasar, akan berkembang lebih baik apabila didukung oleh kondisi fisik yang baik melalui latihan atau berolahraga. Seorang peserta didik akan memiliki kemampuan motor educability yang baik apabila rajin serta aktif dalam berlatih, sehingga nantinya kemampuan tersebut akan memberikan kontribusi kepada individu agar mampu mempelajari secara cepat dan cermat kecakapan dasar dan keterampilan motorik.

Gusril (2007: 11) menjelaskan bahwa "seseorang yang memiliki kemampuan motorik tinggi, diduga akan lebih berhasil dalam menyelesaikan tugas keterampilan motorik khusus". Kemampuan motor educability peserta didik perlu diketahui oleh pelatih, karena saat beraktivitas di lapangan, 
kondisi fisik dan karakter psikologis akan menjadi suatu kesatuan yang saling berinteraksi. Dengan mengetahui kemampuan motor educability peserta didik maka nantinya pelatih akan melakukan penyesuaian kembali program latihan yang cocok bagi peserta didik berdasarkan prinsip-prinsip latihan, dan tujuan yang akan dicapai. Sehingga nantinya pelatih dapat menjadikan keterampilan motorik seperti motor educability pada peserta didik sebagai tujuan untuk mencapai suatu prestasi olahraga. Jika seorang peserta didik memiliki kemampuan motor educability yang baik memperhatikan contoh suatu gerakan, kemudian melakukannya sendiri, maka nantinya hal tersebut akan memberikan kontribusi yaitu persepsi kinestesis yang membutuhkan konsentrasi untuk merasakan suatu gerakan sehingga nantinya peserta didik akan lebih cepat menyerap suatu gerakan.

Di dalam proses pengembangan kemampuan motor educability, para pelatih perlu mempelajari kondisi peserta didik agar penyesuaian metode latihan cocok bagi peserta didik sendiri berdasarkan prinsip latihan dan kemudian tujuan apa yang hendak dicapai. Selain itu, setiap pelatih akan mempunyai gambaran tersendiri tentang keadaan peserta didik dari awal proses latihan sampai kepada inti dan kelangsungan proses latihan itu sendiri.

La Kamadi (2011) menjelaskan pengertian motor educability adalah:

"Kecakapan gerak umum dan tes gerakan-gerakan umum yang dapat diajarkan telah menunjukkan bahwa otoritas masa lampau anak merupakan parameter gerak umum yang sifatnya fundamental untuk keberhasilan partisipasi anak dalam cabang-cabang olahraga mau pun permainan. Kecakapan-kecakapan gerak fundamental ini diperkirakan ditentukan oleh faktor genetis dan stimulasi (rangsangan) dari lingkungan yang dikenalnya sejak dini."

Dari penjelasan diatas dapat dipahami juga bahwa kualitas potensial motor educability memberikan gambaran mengenai kemampuan seseorang dalam mempelajari gerakan-gerakan yang baru dengan mudah. Didalam 
mempelajari keterampilan bolabasket kemampuan motor educability menentukan kualitas teknik yang akan diperoleh oleh peserta didik, hal ini berhubungan dengan cepat tidaknya seseorang peserta didik dalam mempelajari sebuah gerakan ketika ingin menguasai suatu keterampilan pada cabang olahraga tertentu.

Misalnya ketika mempelajari lay-up shoot ada sebagian peserta didik yang mengatakan bahwa gerakannya mudah dan ada sebagian lagi yang mengatakan bahwa gerakannya sulit, dalam hal ini jika pelatih mengukur tingkat motor educability peserta didik tersebut maka akan didapatlah program latihan yang tepat untuk setiap peserta didik.

\section{Peran Motor Educability di Dalam Meningkatan Keterampilan Olahraga Pada Pembelajaran Penjas}

Syafruddin (2013:7) mengatakan:

"Pada dasarnya kegiatan intrakurikuler dan ekstrakurikuler memberikan kesempatan kepada siswa untuk mengembangkan kemampuan belajar motoriknya yang disalurkan melalui kegiatan kecabangan olahraga. Belajar motorik dalam pembinaan olahraga disekolah adalah upaya siswa melalui belajar dan berlatih baik dalam kegiatan intrakurikuler maupun kegiatan ekstrakurikuler untuk menguasai suatu bentuk keterampilan cabang olahraga sehingga ia berprestasi dalam suatu cabang olahraga tertentu sesuai dengan pilihannya. Dengan kata lain terjadi peningkatan kemampuan dan keterampilan yang dimilikinhya."

Teori ini dapat diartikan, bahwa seluruh potensi olahraga yang ada pada seorang peserta didik seharusnya dapat dikembangkan dan dibina melalui proses belajar dan mengajar yang ada disekolah agar nantinya mereka dapat menggunakan potensi yang miliki sebaik mungkin baik di secara pribadi dan berguna untuk masyarakat serta lingkungan. 
Seorang yang bergelut didalam dunia olahraga khususnya bidang pendidikan olahraga memahami setiap aspek yang mempengaruhi perkembangannya sehingga nanti dapat berguna dalam proses pembelajaran itu sendiri.

Kemampuan belajar memahami gerak (motor educability) merupakan salah satu faktor yang penting didalam pengembangan dan pembentukan keterampilan olahraga, Hal ini disampaikan Gusril (2007: 11) yaitu, "seseorang yang memiliki kemampuan motorik tinggi, diduga akan lebih berhasil dalam menyelesaikan tugas keterampilan motorik khusus". Syafruddin (2013: 144) juga mengatakan:

“Orang yang berbakat dan memiliki kemampuan belajar gerak yang baik tentu saja lebih cepat memperoleh suatu keterampilan teknik jika dibandingkan dengan orang yang tidak atau kurang berbakat dan rendah kemampuan intelegensinya (kemampuan kognitifnya)."

Setiap pelatih akan mempunyai gambaran tersendiri tentang keadaan atlet dari awal proses latihan sampai kepada inti dan kelangsungan proses latihan itu sendiri. Hal ini seperti yang dikatakan Kirkendall, et.al, 1987 : 131 di dalam jurnal I Ketut dkk, (2013: 135) yaitu kualitas potensial motor educability memberikan gambaran mengenai kemampuan seseorang dalam mempelajari gerakan-gerakan yang baru dengan mudah. Makin tinggi tingkat potensial motor educabilitynya, berarti derajat penguasaan terhadap gerakangerakan baru makin mudah.

Dari beberapa teori di atas dapat dipahami bahwa mengetahui kemampuan belajar gerak peserta didik sangatlah penting agar seorang pendidik dapat mengetahui kelebihan dan kekurangan seorang peserta didiknya, sehingga nantinya dapat menyesuaikan dengan gaya mengajar melatih ataupun mengajar, program serta perencanaan, fasilitas yang dibutuhkan, dan lain-lain. Sebaliknya, olahraga juga dapat membantu 
perkembangan kognitif peserta didik dengan berbagai latihan didalam pendidikan jasmani.

\section{SIMPULAN DAN SARAN}

Olahraga merupakan bagian yang penting di dalam proses pendidikan, dimana nantinya generasi muda yang baik itu tidak hanya generasi muda yang memiliki kemampuan secara kognitif dan afektif saja, namun juga harus memiliki kemampuan psikomotorik. Oleh karena itu, telah menjadi tugas para guru dan pembina olahraga di sekolah untuk memahami aspek-aspek dari olahraga terutama kemampuan belajar motorik peserta didik, sebagai suatu faktor keberhasilan pengembangan potensi dan keterampilan olahraga dan sebaliknya juga membantu perkembangan kognitif peserta didik.

Bagi seorang pendidik hendaklah lebih teliti lagi dalam memahami aspekaspek yang mempengaruhi perkembangan peserta didik khususnya dalam bidang olahraga. Karena selain kemampuan belajar motorik, masih banyak lagi aspek penting lainnya namun tidak sempat dibahas oleh penulis.

\section{DAFTAR PUSTAKA}

Gusril. 2007. "Peningkatan Kemampuan Motorik Siswa Sekolah Dasar: Pidato Pengukuhan Guru Besar dalam Pedagogik Olahraga papa Fakultas Ilmu Keolahragaan Universitas Negeri Padang”. Padang: Universitas Negeri Padang.

Jariono, Gatot. 2011. Motor Educability. Artikel Online. http://kapasitasmaksimalaerobik.blogspot.com/2011/10/motoreducability.html\# more. Diakses tanggal 19 Maret 2014.

Kamadi, La. 2011. "Pengaruh Gaya mengajar Keseluruhan dan Gaya mengajar Bagian terhadap Penguasaan Keterampilan Dasar Bola Voli Siswa SLTP dengan Tingkat MotorEducability Tinggi dan Rendah: Suatu Studi Eksperimen di SLTP Negeri I Sungguminasa Kabupaten Gowa Sulawesi Selatan”. Jurnal Online Volume 9 Nomor 1 Januari- April 2011. 
http://digilib.unm.ac.id/download.php?id=106 Makasar: Fakultas

Ilmu

KeolahragaanUniversitar Negeri Makasar. Diakses tanggal 19 Maret 2014.

Kementerian Pemuda dan Olahraga. 2005. Undang-Undang RI No. 3 Tahun 2005 tentang Sistem Keolahragaan Nasional. Jakarta: Kementerian Pemuda dan Olahraga.

Lutan, Rusli. 1988. Belajar Keterampilan Motorik, Pengantar Teori dan Gaya mengajar. Jakarta: Departemen Pendidikan dan Kebudayaan Direktorat Jenderal Perguruan Tinggi Proyek Pengembangan Pendidikan Tinggi dan Tenaga Kependidikan.

- 2005. Teori Belajar Keterampilan Motorik Konsep dan Penerapannya. Jakarta:Departemen pendidikan dan Kebudayaan Direktorat Jenderal Perguruan Tinggi ProyekPengembangan Pendidikan Tinggi dan Tenaga Kependidikan.

Samsudin. 2013. Kurikulum Pendidikan Jasmani dan Olahraga. Jakarta: UNJ Press.

Semarayasa, I Ketut dkk. 2013. "Pengaruh Metode Pembelajaran dan Tingkat Motor Educability (Me) terhadap Keterampilan Dasar Smash Kedeng dalam Permainan Sepak Takraw di SMPN 4 Kubutambahan". Jurnal Online Vol. 2, No. 1, April 2013. Singaraja: Jurusan Pendidikan Jasmani Kesehatan dan Rekreasi, Fakultas Olahraga dan Kesehatan Universitas Pendidikan Ganesha. Diakses tanggal 14 Maret 2014.

Syafruddin. 2013. Ilmu Kepelatihan Olahraga: Teori dan Aplikasinya dalam

Pembinaan Olahraga. Padang: UNP Press.

Http://KBBI-Online.co.id Diakses tanggal 21 September 2016 pukul 14:00 WIB. 



\section{miti@JDmmrni}

Perbedaan Yariasi Latihan Juggling dan Rasio Koordinasi Mata-Kaki terhadap Hasil Kontrol Bola dari Tendangan Jarak Jauh Sepak Bola Hengki Kumbara

Hubungan Antara Kekuatan Otot Tungkai dan Kekuatan Otot Lengan terhadap Hasil Kecepatan Renang 50 Meter Gaya Bebas pada Atlet Putri G/ub Bangka Swimming

Farizal lmansyah

Motivasi Mahasiswa PGSD dalam Olahraga Rekreasi di Water Fun KotaPalembang M. Taherisikhbar

Pengaruh Metode Sirkuit terhadap Kemampuan Teknik Dasar Sepakbola pada Kegiatan Eksstrakuivikuler Siswa SIMAN 5 Käbupaten Tebo Alek (oktadinata

Kontribusi Daya Ledak Otot Tungkai dan Kelentukan dengan Elasil Lompat Tinggil Gaya Flop Măhasiswa Program Studi Pendidikan Olahraga Universitas PG:RI Palembang IThams Arvan Junaidi

Kemampuan Menggilling Bola (Studi Korelasional Kecepatan ( $\left(x_{1}\right)$ ) dan Kelincahan ( $\left(x_{2}\right)$ dengan Kemampuan Dribel pada Permainan Sepabola Siswa Se kolahi Menengah Pertama) Putrin Cicilia Kristina

Revitalisasi Masyarakat Uiban/Rerikotaan Melalui Olahraga Retanque Arrdo okilanda

Peranan MataPelajaran Pendidikan Jasmani dalam Meningkatkan Kesadaran Kesehatan Siswa di Lingkungan Sekrolah Dasar

Negexi [ul Tegalkalong Kabupaten sumedang $\mathbb{N}_{0}$ Siti nuraeni Sofa dan Anggi Setia Lengkana

Peran Motop Educabilitis di dalam Meningkatan Keterampilan Olahraga pada Pembelajaran Penjas Feru Syarili Lesmana

MotivasiAnggota Pusat Kebugaran dalam Mengikuti Latihan Fithess pada Kota Sekayu Sugar Wanto

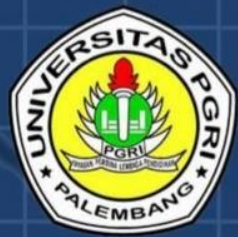

Program Studi Pendidikan Olahraga Fakultas Keguruan dan Ilmu Pendidikan Universitas PGRI Palembang 


\section{HALAMAN OLAHRAGA NUSANTARA}

Jurnal Ilmu Keolahragaan

Volume 1, Nomor 1, Januari 2018

Pelindung/Penasehat

Dr. H. Bukman Lian, M. M., M. Si.

Penanggung Jaw ab

Dr. Dessy Wardiah, M. Pd.

Ketua Dew an Redaksi

Drs. M. Nirwan, M. Pd.

\section{Wakil Ketua Dew an Redaksi}

Ilham Arvan Junaidi, M. Pd.

\section{Sekretaris}

Nasrullah, M. Pd.

\section{Penyunting Pelaksana}

Rafel Orlando, M. Pd

Ardo Okilanda, M. Pd

\section{Penyunting Ahli/ Mitra Bestari}

Prof. Dr. A. Sofyan Hanif, M. Pd (Universitas Negeri Jakarta)

Dr. Roni Yenes, M. Pd (Universitas Negeri Padang)

Dr. Putri Cicilia Kristina, M. Pd (Universitas PGRI Palembang)

\section{Tata Usaha}

M. Taheri Akbar, M. Pd

Setting:

Dede Dwiansyah Putra, M. Pd

\section{Alamat Redaksi:}

Prodi Pendidkan Olahraga Fakultas Keguruan Ilmu dan Pendidikan Universitas PGRI Palembang

J1. Jendral A. Yani Lorong Gotong Royong 9/10 Ulu Palembang Telp. 0711-510043, Fax. 0711-514782 e-mail jurnal: rafelorlando333@ gmail.com e-mail : ardo.oku@univpgri-palembang.ac.id website: univpgri-palembang.ac.id 
Halaman Olahraga Nusantara

ISSN 2614-2775

Volume 1, No. 1, Januari 2018

\section{DAFTAR ISI}

Hasil Penelitian

Halaman

Perbedaan Variasi Latihan Juggling dan Rasio Koordinasi Mata-Kaki terhadap Hasil Kontrol Bola dari Tendangan Jarak Jauh Sepak Bola

- Hengki Kumbara

Hubungan Antara Kekuatan Otot Tungkai dan Kekuatan Otot Lengan terhadap Hasil Kecepatan Renang 50 Meter Gaya Bebas pada Atlet Putri Club Bangka Swimming

- Farizal Imansyah

Motivasi Mahasiswa PGSD dalam Olahraga Rekreasi di Water Fun Kota Palembang

- $\quad$ M. Taheri Akhbar

Pengaruh Metode Sirkuit terhadap Kemampuan Teknik Dasar Sepakbola pada Kegiatan Ekstrakurikuler Siswa SMAN 5 Kabupaten Tebo

- Alek Oktadinata ...................................................

Kontribusi Daya Ledak Otot Tungkai dan Kelentukan dengan Hasil

Lompat Tinggi Gaya Flop Mahasiswa Program Studi Pendidikan

Olahraga Universitas PGRI Palembang

- Ilham Arvan Junaidi

Kemampuan Menggiring Bola (Studi Korelasional Kecepatan $\left(\mathrm{x}_{1}\right)$ dan Kelincahan $\left(\mathrm{x}_{2}\right)$ dengan Kemampuan Dribel pada Permainan Sepabola Siswa Sekolah Menengah Pertama)

- Putri Cicilia Kristina

Revitalisasi Masyarakat Urban/Perkotaan Melalui Olahraga Petanque

- Ardo okilanda

Peranan Mata Pelajaran Pendidikan Jasmani dalam Meningkatkan

Kesadaran Kesehatan Siswa di Lingkungan Sekolah Dasar

Negeri III Tegalkalong Kabupaten Sumedang

- $\quad$ N. Siti nur'aeni Sofa dan Anggi Setia Lengkana

Peran Motor Educability di dalam Meningkatan Keterampilan

Olahraga pada Pembelajaran Penjas

- Heru Syarli Lesmana 
Motivasi Anggota Pusat Kebugaran dalam Mengikuti Latihan Fitness pada Kota Sekayu

- Sugar Wanto $126-13$ 